\title{
Research on Negotiated Teaching Mode in English Listening Teaching
}

\author{
Caiqiao Huo', Xiaomei Du¹, Weichen Gu² \\ ${ }^{1}$ School of Foreign Language Education and International Business, Baoding University, Baoding, China \\ ${ }^{2}$ Foreign Language College, Hebei Normal University, Shijiazhuang, China \\ Email: goofyhuo@163.com
}

How to cite this paper: Huo, C. Q., Du, X. M., \& Gu, W. C. (2018). Research on Negotiated Teaching Mode in English Listening Teaching. Creative Education, 9, 2477-2482. https://doi.org/10.4236/ce.2018.915186

Received: October 15, 2018

Accepted: November 13, 2018

Published: November 16, 2018

Copyright (c) 2018 by authors and Scientific Research Publishing Inc. This work is licensed under the Creative Commons Attribution International License (CC BY 4.0).

http://creativecommons.org/licenses/by/4.0/

\section{(c) (i) Open Access}

\begin{abstract}
Among the four skills of studying English, listening which is the most important way to obtain language information and improve the other three skills comes the first. However, it is very difficult for most English learners to improve their listening ability. There are many factors that contribute to this phenomenon: one is that students didn't get systematical listening training in high school; the other is that the monotonous teaching model makes students lose interest in listening to English. This study aims to change the traditional English teaching method by applying the Negotiated Teaching Mode to English listening teaching. English majors from two classes of a university were selected as the subjects. The research lasted for eighteen weeks. The results showed that compared with the control class, English listening performance of the experimental class was significantly improved. Students from the experimental class had more positive changes in their interests and listening abilities, which indicated that this teaching mode was feasible.
\end{abstract}

\section{Keywords}

Negotiated Teaching Mode, English Listening Teaching

\section{Introduction}

The negotiated course was proposed in Australia and the United States in the late 1980s and early 1990s. The main advocates are G. Boomer, J. Cook and N. Lester et al. The advocates believe that we are facing challenges in terms of global culture, economy and ecology. As one of the main means to cope with challenges, education must go beyond the so-called "basic learning" which is dominated by traditional methods. They insist that education should cultivate stu- 
dents' critical, inquiry, and flexible thinking skills. The completion of this educational goal requires a new curriculum development model. Therefore, negotiated courses and consultation learning are brought forward based on this background (Sun, 2007).

In China, scholars have started to pay attention to negotiated interaction since late twentieth century. English teaching in China has its own unique linguistic and cultural background and language learners have their own unique physical and psychological characteristics, which determine that we should take Chinese characteristics into consideration while learning from foreign countries and try to explore teaching ways with Chinese features ( $\mathrm{Lu}, 2011)$.

At present, too much emphasis is put on the dominant role of teachers, and students' subjectivity is ignored in English listening teaching. In this study, the researcher applies Negotiated Teaching Mode to English listening teaching and aims to find new ways to improve English learners' listening ability.

\section{Research Background}

Many scholars have conducted research on the Negotiated Teaching Mode and English teaching. Lyster believes that the difference between meaning-focus and form-focus negotiation is very important. Negotiation in classroom should not be meaning-focused. For an experienced teacher, it is necessary to pay attention to forms (Lyster, 2002). Long puts forward the idea of negotiation for meaning and claims that native speaker and nonnative speakers change their conversation structures when they don't understand each other through repetition, confirmation and clarification requests (Long, 1980). Xiao Longhai emphasizes that the development of students' subjectivity is an important subject in education reform. Negotiated course are courses in which teachers and students discuss together to determine what to study and how to study. To meet the needs of students to learn actively and efficiently, negotiated courses can change the passive learning status of students and make students take initiative in studying (Xiao, 2001).

Sun Laicheng pointed out that negotiated learning comes from the learners' sense of self-study, which comes from the satisfaction of learners' needs, interests, and aspirations. Negotiated study provides us with a new perspective on negotiating learning that is embedded in dialogue (Sun, 2007).

Cui Dazhi pointed out that autonomous learning is a distinctive feature of modern education. Autonomous learning means that learners shoulder the responsibility of learning. The core of foreign language autonomous learning is that the teacher and students negotiate to set up teaching aim, design teaching activities and complete the evaluation. Negotiated Teaching Mode enables students to have the right to decide what they study and be the master of their studying. Negotiated Teaching Mode embodies a flexible, dynamic, open approach in foreign language teaching. Teachers and students make progress together during the process of negotiation (Cui, 2010). 


\section{Study Design}

\subsection{The Objective of the Study}

In order to stimulate students' interest in English listening and eliminate their anxiety while listening, teachers apply the negotiated Teaching Mode to listening teaching. The objective of this study is to figure out whether negotiave teaching method is helpful to improve students' listening ability.

\subsection{The Subject of the Study}

English majors from two classes in one university are involved in this study. They are freshmen taught by the same teacher. The listening ability of these two classes is nearly of the same level. One class is experimental class and the other is control class. The difference is that negotiated teaching method is used in the experimental class, while traditional teaching method is used in the control class.

\subsection{Instruments}

The indicators used in the survey are English listening test scores. The test papers used for the test are professional English listening test papers. The test papers include three parts: short conversations, long conversations and passages, and the full score is 100 points.

\subsection{Data Collection and Processing}

The study begins in March 2018 and ended in June 2018 for a period of eighteen weeks. Students take part in the final at the end of the nineteenth week.

\section{Results}

In order to explore whether the negotiated teaching method is conducive to improving the students' listening comprehension ability, the author conducted the pre-test and the post-test for two parallel classes. The results of the pre-test are shown in Table 1.

Table 1 shows that the number of students in the experimental and control classes was 31 respectively. The average score of the experimental class was 69.49 and the standard deviation was 9.27; the average score of the control class was 70.03 and the standard deviation was 11.11 .

The results of the pre-test of independent-samples $\mathrm{T}$ test for two parallel classes are shown in Table 2.

Table 2 shows that the average score of pre-test was respectively 69.49 and 70.03 , and the average score of the experimental class was slightly lower than that of the control class. It can be found that there was no significant difference in the scores of the two parallel classes $(t=0.843, p=0.490, p>0.05)$. Therefore, It can be inferred that the listening ability of the two parallel classes before the study is nearly of the same level.

The results of the post-test of independent-samples $\mathrm{T}$ test for two parallel 
classes are shown in Table 3.

Table 3 shows that the average score of post-test was respectively 80.22 and 72.15 , and the average score of the experimental class was obviously higher than that of the control class. It can be found that there was significant difference in the scores of the two parallel classes $(\mathrm{t}=1.529, p=0.003, p<0.05)$.

\section{Discussion}

Based on the above research, it can be concluded that the negotiated teaching method is helpful to improve the students' listening comprehension ability, and the reasons can be summarized as follows:

1) It is helpful to fully embody the main body status of students in teaching activities.

The traditional English listening teaching method focuses on making students listen to listening materials passively, neglecting the cultivation of students' independent thinking ability, lacking the training of students' personality development, and neglecting students' initiative and enthusiasm in learning. Through negotiated teaching method, students can have greater initiative in selecting listening materials, learning methods and so on, so that students' subjectivity in teaching activities can be fully reflected and exerted.

2) It is helpful to arouse students' interest in Learning.

Theoretically, interest is the internal motivation to stimulate students' learning, and it is also an important factor in deciding whether students can learn consciously and actively. Because the traditional English listening teaching method ignores the students' interest in learning, the teaching contents are limited to textbooks, and the teaching methods are too rigid. In fact, many students like listening to authentic English materials, but they do not like the contents taught in class. The negotiated teaching method emphasizes the cooperation and

Table 1. The results of the pre-test of listening test.

\begin{tabular}{ccccc}
\hline Class & $\begin{array}{c}\text { The Number of } \\
\text { Students }\end{array}$ & Mean & Std. Deviation & Std. Error Mean \\
\hline Experimental Class & 31 & 69.49 & 9.27 & 1.4537 \\
Control Class & 31 & 70.03 & 11.11 & 1.6712 \\
\hline
\end{tabular}

Table 2. Independent samples test.

\begin{tabular}{ccccc}
\hline Class & Mean & Std. Deviation & $\mathrm{t}$ & $p$ \\
\hline Experimental Class $(\mathrm{n}=31)$ & 69.49 & 9.27 & & \\
Control Class $(\mathrm{n}=31)$ & 70.03 & 11.11 & 0.843 & 0.490 \\
\hline
\end{tabular}

Table 3. The results of the post-test of listening test.

\begin{tabular}{ccccc}
\hline Class & Mean & Std. Deviation & $\mathrm{t}$ & $p$ \\
\hline Experimental Class $(\mathrm{n}=31)$ & 80.22 & 7.31 & & \\
Control Class $(\mathrm{n}=31)$ & 72.15 & 10.46 & 0.003 \\
\hline
\end{tabular}


interaction between teachers and students, and respects students' needs and interests in learning. Therefore, it can stimulate students' interest in listening. Teachers can select the contents of listening according to the result of discussion with students and appropriately increase listening materials which are interested by students. After class, teachers can also assign some listening tasks to students, such as listening to English songs, watching English movies, etc., and make students give a short report in the next class (Liu \& Zheng, 2008).

3) It is helpful to widen students' scope of knowledge.

Through negotiation, members of the class can share various social and cultural resources, which is more resourceful than teacher or individual. The teacher can understand what the students want to learn and students can provide good ideas to make class more effective and interesting. During the process of negotiation, students can understand each other much better. Because different student has different tastes in listening, this method can encourage them to enrich the contents of the listening class. Finally, students are able to broaden their horizons.

\section{Conclusion}

The conclusion of this study is that negotiated listening teaching method can stimulate students' listening interests, and enhance students' sense of responsibility for autonomous learning. It conforms to the basic rules of second language acquisition, and is able to improve students' listening comprehension ability under the international environment. The enlightenment to English listening teaching is that negotiated teaching method is feasible in the English listening teaching in the era of network. However, due to the limited experimental conditions, experimental scope and experimental time, whether this method is helpful to foreign language students in others universities needs further research and investigation in the future.

\section{Acknowledgements}

The paper is under the project of Research on the Practice of Negotiated Teaching Method in College English Listening Teaching (Project No. 171073) which is sponsored by Baoding Municipal Institute of Education and Teaching and the project of Research and Practice of Multi-modal Functions in Listening Teaching of English Majors (Project No. 2015J01) which is sponsored by Baoding University. All the project members made their contributions to the paper. We also thank all our friends and classmates who work in different universities, which made the investigation possible.

\section{Conflicts of Interest}

The authors declare no conflicts of interest regarding the publication of this paper. 


\section{References}

Cui, D. Z. (2010). Study on the Negotiation Mode in Foreign Language Independent Study. Journal of Liaoning Normal University (Social Science Edition), No. 6, 64-66.

Liu, H., \& Zheng, Z. L. (2008). A Study of Cooperative Learning in English Listening Class for Vocational College Students. Journal of Jixi University, No. 5, 89-92.

Long, M. H. (1980). Inside the "Black Box": Methodological Issues in Classroom Research on Language Learning. Language Learning, No. 30, 1-42.

Lu, X. J. (2011). Negotiation Classroom Mode in College English Teaching. Read and Write Periodical, No. 10, 15-16.

Lyster, R. (2002). Negotiation in Immersion Teacher-Student Interaction. International Journal of Educational Research, No. 37, 237-253.

Sun, L. C. (2007). On Negotiated Studying. China Adult Education, No. 22, 113-114.

Xiao, L. H. (2001). Negotiating the Curriculum: A Curriculum Model of Efficient Learning. Comparative Education Review, No. 8, 20-23. 